(20) MoTt.-Med. Clin. Tirns., vol. Ixxxii, 19(0), found leukamic infiltration in cochlea and canals.

(21) Lavvors.-Annul. des Mal. de looville, etc., 1892; found extravasation of blood in restibule and in canals undergoing organisation; new connectur.. tissue formation in the bony canals; cellular infiltration in scala vestibuli of firet turn of cochlea.

(22) Parkes-Weber and Lakf.-Pror. Roy. Med. and C'7in. Sor., 19x): fomml new formation of fibrous and bony tissue in the scalat tympani and in the lerilymphatic spacess of the canals.

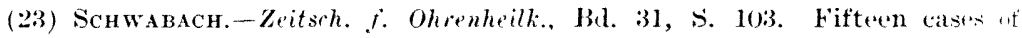
leukamic deafness; five had apoplectiform attitcks.

(24) Kock,-Ibid., Bd. 5), s. 431. Hemorrhage in cochleat and canals.

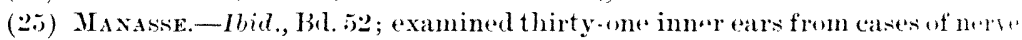
deafness, and found two with evidences of labyrinthine hamorrhages in achlition th degenerative changes.

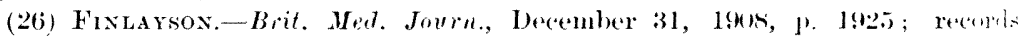
another leukamic case with hamorrhage in vestibule and first turn of corhleat.

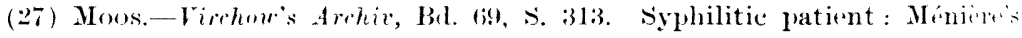
symptoms engrafted on existing ear disease; periostitis in vestihule: small-wll infiltration of membramous labyrinth.

(28) Have,- " Dit Krankheiten des ohres in ihren Beziehungen," etc., Molis. Tabetic catse: the acoustic nerve-panglion and accessory ganglia were affected.

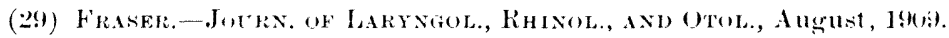

\title{
A NEW CONTRIBUtion TO THE OPERATIVE TECHNIQUE OF THE LABYRINTH.
}

BY DR. Burricert, Chef de Clinique of the Faculty of Medicine, 'Toulouse.

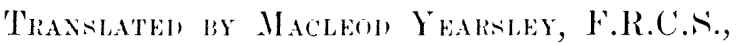
senior Surgeon to the Royal Ear Hospital.

Is 1905, in our inangural thesis, "The Surgical Anatomy of the Labyrinth," we showed how we should understand the opening of the internal ear in case of diffuse suppurative labyrinthitis. We then extolled the opening of the cochlea and of the anterior branch of the external semi-circular canal, and as the facial nerve parses parallel to this anterior branch, we constructed a protector in orlen not to injure it. The French school, despite Lermoyez's article in La Presse Mrdicale at Bordeaux in 1904, the French school, we say, does not stimulate research in this matter. The Viennese school, on the contrary, with Alexander, Neumann, and Bárány (1), has used every effort to unravel and make precise the somewhat delicate symptomatology of this organ. The first of all these

I Slightly abridged from the Bulletins et Mémoires de la société Francaise dotuRhino-Laryngologie, 1909. 
restarches is recorded in a momograph of Barany, aswistant in Pulitzer's clinic, in 1907. It is in comsequence of this work that in France the experimental and pathological uystagmus of the restilular apparatus is investigated. Lombard and Halphen (2), the rame year, published a work "On Elicited Reflex Nrstagmus as a liagnostic Method in Functional Conditions of the Vestibular. Apparatus." I'ietri (3), in the denemal de Medecine de Bomdeder, smeles elicited nystagmus in his reports with the labyrinthine atfertions, and, a little later, the same author, in collaboration with Manpetit (H), studies this same nystagmus alant from all patholueveal affection. Hautaut (i), lematere and Halphen (i) have equally stmbied this subject.

Wh ourselves are atgain occupied with the surgery of the intermal ear, and it is the result of this work that we would describe.

Wremsider that the opening, such as we practised ( 7 ), was insufficient, for we left the frontal, sachital, and the posterior hanch of the horizontal anal intact. Nerertheless, all these fatpts may contain pus in a case in which the suppuration is diffuse. The operation was incomplete, since we left a source of infection which might cause a meningitis or any other cerebral complication to follow. At the present time we open all the canals, making the operation as extensive as possible. The following is om method if procedure:

At the beginning, to make a large excavation, carrying it as tar hack as possible; reaching above to the posterior probongation of the gygomatic arch and to the point at which this areh recurves, and to remove as much as possible of the buttress over the facial, $\therefore$ as to bring part of the oval and romed windows well inte view. This is most important if it is wished to obtain a very clear view wer the promontory. To facilitate this inspection it is good to reect the whole of the posterior wall of the membranous auditory meatus. In this axcavation the descending branch of the lateral simus is often laid bare, especially if it is slightly procident. Exavation thas practised extensively, the anterior branch of the herizontal canal is very clearly seen; the edge of a sufficiently fine gonge is then applied to the point at which this canal changes its direction, and its curve is opened by one cut. Then, parallel to the huttress over the facial between it and the sinus, going from below up and a little behind forwards, the bone is excavated more and more deeply. The posterior canal is opened at its deepest part. 
In a second stage digging with the gouge is continued betwee the sinus and the buttress over the facial, taking as a landmat the posterior branch of the horizontal canal, thus working behin the facial and on a plane slightly inferior, thus going in a forwar direction. By this means the vestibule is opened in its posterio part. It is sufficient to take a light curette, to introduce it int the vestibule by the artificial opening, and to make it come ont a the oval window, passing under the facial, in order to make sur that the vestibule is well opened behind.

In a third stage the heel of our protector (which we hav modified) is introduced into the oval window, the metallic plate weasuring about $3 \mathrm{~mm}$., hugging the aqueduct of Fallopius, si a to protect the facial. The protector is held by an assistant. Witl the help of a graving chisel, this smooth, polished prominence 0 the aditus is removed from behind forwards, and the anterio branch of the horizontal canal is opened. The plate of the pro tector prevents the graving chisel from going astray towards the lower part and injuring the facial; similarly the beak of thi: same protector protects the nerve in front in cases where the chisel may tend to slip forward. It is enough, further, if the excavation has been large and sufficiently extended above, to give two cuts of the chisel in the vertical direction, at the poin where the ampullary orifice of the horizontal canal has beer opened, to lay bare the ampullary orifice of the frontal cana and a part of its anterior branch.

In a last stage, the protector remaining in place, the pro. montory can be ablated by means of a gouge, without any difficulty. It is enough to rest the convexity of the instrument against the buttress over the facial, the edge of the gouge appliec on the line of separation of the round and oval windows, and ti give a cut, followed by another cut on the side of the orifice of the Eustachian tube. 'This is sufficient to remove the cap of the cochlea formed by the promontory.

'J'hus the vestibule is laid open behind, by following the posterior branch of the horizontal canal; above, by opening the two ampullary orifices of the two canals, external and frontal; below, by throwing the two windows, oval and round, into one.

(1) Bárány.- "Physiologie und Pathologie des Bogengan-Apparates beim Menschen,” 1907.

(2) Lombard and Hatphen,-Progrès Médicul, April 18, 1907.

(3) Pı́tri.-Journal de Médecine de Borleuux, April, 1908.

(4) Pietri and Maupetit.- - Elicited Nystagmus Apart from all Pathological Affection," Rev. de Laryngol., November 21, 1908, p. 609. 
(5) Hautant.-- “ Functional Examination of the Semi-circular Canals by Reflex Xystagmus," Ann. des Mal. de l'Oreille, September, 1908, p. 245.

(i) Lemaître and Ha lphen.- "Nystagmus and the Internal Ear," ibid., p.673.

(7) Bourquet, - "Surgery of the Lahyrinth," ihid., 1905, t. ii, p. 218.

\title{
THE SENSORY SYMPTOMATOLOGY AND SYNDROME OF THE FACIAL NERYE : OTALGIA, HERPETIC INFLAMMATIONS OF THE GENICULATE GANGLION, REFLEX FACIAL SPASMS. ${ }^{1}$
}

\author{
By J. RaMsay Hunt, \\ New York.
}

A REVIEW of the sensory symptomatology of the facial nerve, with special reference to the following contributions by the author: "(On Herpetic Inflammations of the Geniculate Ganglion; a New sundrome and its Complications," Joumal of Nerrous and Mental Diseases, February, 1907. "A Further Contribution to the Herpetic Inflammations of the Geniculate Ganglion, American Jonernal of Amtrican sciences, August, 1908. "Otalgia Considered as an Affection of the Seventh Cranial Nerve," Archices of ()tology, July, 1908. "The Sensory System of the Facial Nerve and its Symptomatology," Journal of Nercous and Mental Dixeases, June, 1909, by J. Ramsay Hunt, M.D., of New York.

The author reviews his contributions to the sensory symptomatology of the facial nerve. The facial nerve has been regarded as a mixed nerve by anatomists and embryologists for a decade or more, and as having a sensory root and ganglion similar in structure and function to the sensory ganglia of the spinal nerves and those of the mixed cranial nerves. This ganglion is called the geniculate ganglion, or the intumescentia ganglioformis, situated in the depths of the internal auditory canal at the entrance to the aqueduct of Fallopius, at which point the trunk of the facial nerve makes a sharp bend. The sensory root of this ganglion is the pars intermedia of Wrisberg, which lies between the facial proper and the auditory nerve. The nerve of Wrisberg enters the substance of the medulla between the roots of the seventh and eighth nerves and passes to the fasciculus solitatius, having the same mode of termination as the sensory roots of the glassopharyngeal and the vagus nerves. On the distal side of the geniculate ganglion, sensory fibres pass into the great superficial petrosal nerve to

1 Journ. of Nerv, and Mental Dis., vol. xxxvi, No. 6, 1909, etc. 